\title{
Pengaruh Profitabilitas pada Agresivitas Pajak dengan Pengungkapan CSR Sebagai Variabel Moderasi
}

\section{Dewa Ayu Nyoman Shintya Devi ${ }^{1}$ Luh Gede Krisna Dewi ${ }^{2}$}

${ }^{1,2}$ Fakultas Ekonomi dan Bisnis Universitas Udayana (Unud), Bali, Indonesia e-mail: shintyadevi11@yahoo.com

\begin{abstract}
ABSTRAK
Penelitian ini bertujuan untuk memeroleh bukti empiris pengaruh profitabilitas pada agresivitas pajak. Penelitian ini juga bertujuan memeroleh bukti empiris kemampuan pengungkapan Corporate Social Responsibility (CSR) memoderasi pengaruh profitabilitas pada agresivitas pajak. Penelitian dilakukan pada perusahaan pertambangan yang terdaftar di Bursa Efek Indonesia (BEI) periode 2014-2017. Sampel ditentukan melalui metode non probability sampling dengan teknik purposive sampling. Jumlah sampel yang digunakan dalam penelitian ini berjumlah 56 sampel amatan. Teknik analisis data yang digunakan adalah analisis Moderated Regression Analysis (MRA). Hasil dari penelitian ini menunjukkan bahwa profitabilitas berpengaruh positif pada agresivitas pajak. Hasil menunjukkan pengungkapan CSR tidak memoderasi pengaruh profitabilitas pada agresivitas pajak. Implikasi penelitian secara teoritis membuktikan Teori Agensi dan Teori Akuntansi Positif dalam menjelaskan agresivitas pajak.
\end{abstract}

Kata kunci: Agresivitas pajak, profitabilitas, corporate social responsibility.

\begin{abstract}
This study aims to obtain empirical evidence of the effect of profitability on tax aggressiveness. This study also provides empirical evidence of the ability to disclose Corporate Social Responsibility (CSR) to moderate the influence of profitability on tax aggressiveness. Research conducted on companies published on the Indonesia Stock Exchange (IDX) for the 2014-2017 period. The sample is determined through non probability sampling method with purposive sampling technique. The number of samples used in this study were 56 observation samples. The data analysis technique used is the analysis of Moderated Regression Analysis (MRA). The results of this study indicate that profits show a positive effect on tax aggressiveness. The results show CSR disclosure does not moderate the effect of profitability on tax aggressiveness. Agency Theory and Positive Accounting Theory in explaining tax aggressiveness.

Keywords: Tax aggressiveness, profitability, corporate social responsibility.
\end{abstract}

\section{PENDAHULUAN}

Definisi pajak berdasarkan Undang-Undang Nomor 28 Tahun 2007 pada pasal 1 ayat 1, ialah kontribusi wajib kepada negara yang terutang oleh orang pribadi maupun badan yang bisa dipaksakan, didasari atas Undang-Undang, tanpa mendapatkan imbalan langsung dan dimanfaatkan untuk membiayai keperluan 
negara bagi sebesar-besarnya kemakmuran rakyat. Pajak memiliki dua fungsi yakni berfungsi sebagai anggaran (budgetair) serta sebagai pengatur (regulerend). Pajak berfungsi sebagai anggaran yang artinya, pajak merupakan salah satu sumber penerimaan pemerintah untuk membiayai pengeluaran rutin maupun pembangunan. Menurut Tiaras dan Wijaya (2015), penerimaan pajak negara memiliki persentase terbesar dari total penerimaan negara secara keseluruhan. Pajak sebagai sumber penerimaan negara yang paling berperan dalam kontribusi pembangunan negara

Penerimaan pajak di Indonesia saat ini masih belum maksimal (Dewi dan Noviari 2017). Hal ini dibuktikan dengan ketidakmampuan pemerintah untuk merealisasikan target penerimaan pajak pada periode 2014-2017, hal tersebut disajikan pada Tabel 1 sebagai berikut.

Tabel 1.

Target serta Realisasi Penerimaan Pajak Tahun 2014-2017 (Dalam Triliun Rupiah)

\begin{tabular}{cccc}
\hline Tahun & Target Penerimaan Pajak & $\begin{array}{c}\text { Realisasi Penerimaan } \\
\text { Pajak }\end{array}$ & Persentase \\
\hline 2014 & $1.072,37$ & 985,13 & 91,56 \\
2015 & $1.294,25$ & $1.060,83$ & 81,96 \\
2016 & $1.355,20$ & $1.105,81$ & 81,60 \\
2017 & $1.283,56$ & $1.151,13$ & 89,68 \\
\hline
\end{tabular}

Sumber: Laporan Kinerja Direktorat Jenderal Pajak, 2018

Tabel 1 menunjukkan bahwa realisasi penerimaan negara yang bersumber dari pajak di Indonesia periode 2014-2017 mengalami peningkatan di setiap tahunnya namun peningkatan tersebut belum mampu mencapai target yang telah ditentukan di setiap tahunnya.

Kinerja penerimaan pajak juga dapat dilihat dari tax ratio (rasio pajak). Rasio pajak adalah perbandingan atau persentase penerimaan pajak terhadap 
produk domestik bruto (PDB). Darmawan dan Sukartha (2014) berpendapat bahwa apabila rasio pajak suatu negara tinggi, maka semakin baik kinerja pemungutan pajak negara tersebut. Menurut laporan tahunan Direktorat Jenderal Pajak (DJP) 2017, Indonesia mengalami penurunan tax ratio dari tahun 2014 hingga 2017. Tax ratio tahun 2014 berturut-turut hingga 2017 yakni 13,1 persen, 11,6 persen, 10,8 persen dan 10,7 persen. Persentase tax ratio yang menurun menandakan bahwa kinerja pemungutan pajak oleh pemerintah masih belum optimal.

Wiguna dan Jati (2017) berpendapat bahwa penerimaan pajak di Indonesia yang masih belum maksimal, mengindikasikan ada kemungkinan yakni dari sisi wajib pajak terdapat beberapa tindakan yang dilakukan untuk meminimalkan pajaknya, atau pemungutan pajak yang dilakukan pemerintah belum mampu berjalan secara maksimal. Putra dan Merkusiwati (2016) berpendapat bahwa upaya efisiensi pajak oleh wajib pajak adalah salah satu faktor yang memengaruhi penerimaan pajak. Efisiensi pajak dikaitkan dengan sifat pajak yang dapat dipaksakan serta tidak mendapat kontraprestasi secara langsung, membuat pelaksanaan pemungutan pajak oleh pemerintah tidak selalu mendapat sambutan baik bagi wajib pajak.

Perusahaan termotivasi untuk meminimalkan beban pajak yang harus dibayar kepada pemerintah (Diantari dan Ulupui 2016). Perusahaan sebagai subjek wajib pajak badan mempunyai kewajiban untuk membayar pajak namun, bagi perusahaan pajak merupakan beban yang akan mengurangi laba bersih. Perbedaan kepentingan timbul karena fiskus ingin memeroleh penerimaan pajak 
Dewa Ayu Nyoman Shintya Devi dan Luh Gede Krisna Dewi. Pengaruh ...

yang tinggi dari masyarakat, namun di sisi lain perusahaan menginginkan membayar pajak yang seminimal mungkin kepada negara. Perbedaan kepentingan antara fiskus dan perusahaan akan mengarahkan wajib pajak atau pihak manajemen perusahaan pada ketidakpatuhan pajak, sehingga perusahaan berupaya melakukan agresivitas pajak.

Menurut Frank et al. (2009), agresivitas pajak adalah suatu tindakan yang dilakukan perusahaan untuk menurunkan penghasilan kena pajak dengan perencanaan pajak yang dilakukan sesuai dengan peraturan perpajakan yang berlaku (tax avoidance) atau dari perilaku ketidakpatuhan akan peraturan perpajakan (tax evasion). Agresivitas pajak sebagai suatu aktivitas spesifik mencakup transaksi-transaksi yang bertujuan untuk menurunkan kewajiban pajak perusahaan (Slemrod, 2004). Lanis dan Richardson (2013) berpendapat bahwa agresivitas pajak umumnya ditemukan dalam bentuk transaksi yang berkaitan dengan penggunaan berlebihan atas utang perusahaan, beban bunga, serta kerugian pajak. Perusahaan yang semakin memanfaatkan celah peraturan untuk menghemat beban pajak maka perusahaan dapat dianggap telah melakukan agresivitas pajak meskipun tindakan tersebut tidak menyalahi peraturan yang ada.

Kasus agresivitas pajak kerap ditemukan oleh pihak berwenang dalam bentuk penghindaran pajak yang ditemukan di berbagai sektor usaha, salah satu yang berpotensi dan kerap melakukan agresivitas pajak adalah sektor pertambangan. Tabel 2 menampilkan penerimaan pajak per Klasifikasi Lapangan Usaha (KLU) berdasarkan Kepdirjen Nomor KEP-321/PJ/2012 yang digolongkan menjadi 21 kategori kegiatan ekonomi wajib pajak di Indonesia sebagai berikut: 
Tabel 2.

Penerimaan Pajak per Klasifikasi Lapangan Usaha (KLU) 2014-2017 (Dalam Miliar Rupiah)

\begin{tabular}{ccccc}
\hline Kode & 2017 & 2016 & 2015 & 2014 \\
\hline A & $17.457,17$ & $14.155,95$ & $18.382,62$ & $15.033,12$ \\
B & $103.723,85$ & $73.674,39$ & $102.196,35$ & $117.331,89$ \\
C & $333.601,26$ & $283.897,75$ & $284.640,48$ & $289,669,92$ \\
D & $23.396,08$ & $30.437,11$ & $22.563,60$ & $13.951,27$ \\
E & $2.018,43$ & $1.652,38$ & $1.740,19$ & $1.425,89$ \\
F & $59.373,43$ & $55.230,411$ & $59.542,62$ & $47.310,59$ \\
G & $194.713,66$ & $156.460,47$ & $154.256,86$ & $129.780,95$ \\
H & $36.264,90$ & $32.445,66$ & $33.654,64$ & $28.541,17$ \\
I & $4.970,30$ & $4.473,97$ & $4.822,42$ & $3.991,94$ \\
J & $44.871,26$ & $40.786,23$ & $33.797,82$ & $29.393,29$ \\
K & $145.803,30$ & $135.194,68$ & $153.189,55$ & $113.474,88$ \\
L & $20.590,98$ & $19.402,85$ & $24.026,48$ & $20.067,78$ \\
M & $23.721,02$ & $20.171,21$ & $19.995,65$ & $17.595,49$ \\
N & $11.334,09$ & $9.763,12$ & $9.887,68$ & $8.444,31$ \\
O & $36.274,44$ & $36.877,78$ & $36.157,05$ & $29,299,02$ \\
P & $2.888,00$ & $2.820,26$ & $2.837,91$ & $2.112,14$ \\
Q & $4.636,09$ & $3.955,19$ & $3.815,10$ & $2.796,44$ \\
R & $1.292,44$ & 991,87 & 955,36 & 808,28 \\
S & $13.239,34$ & $10.560,44$ & $11.553,65$ & $7.991,07$ \\
T & 192,34 & 157,22 & 154,35 & 106,98 \\
U & 98,08 & 87,70 & 20,54 & 9,80 \\
\hline
\end{tabular}

Sumber: Laporan Tahunan Direktorat Jenderal Pajak, 2018

Keterangan:

Kode A : Pertanian, Kehutanan dan Perikanan

Kode B : Pertambangan dan Penggalian

Kode C : Industri Pengolahan

Kode D : Pengadaan Listrik, Gas, Uap/Air Panas dan Udara Dingin

Kode E : Pengadaan Air, Pengelolaan Sampah dan Daur Ulang, Pembuangan dan Pembersihan Limbah dan Sampah

Kode F : Konstruksi

Kode G : Perdagangan Besar dan Eceran; Reparasi dan Perawatan Mobil dan Sepeda Motor

Kode $\mathrm{H}$ : Transportasi dan Pergudangan

Kode I : Penyediaan Akomodasi dan Penyediaan Makan Minum

Kode $\mathbf{J}$ : Informasi dan Komunikasi

Kode K : Jasa Keuangan dan Asuransi

Kode L : Real Estate

Kode M : Jasa Profesional, Ilmiah dan Teknis

Kode N : Jasa Persewaan, Ketenagakerjaan, Agen Perjalanan dan Penunjang Usaha Lainnya

Kode O : Administrasi Pemerintahan dan Jaminan Sosial Wajib

Kode P : Jasa Pendidikan

Kode Q : Jasa Kesehatan dan Kegiatan Sosial

Kode R : Kebudayaan, Hiburan dan Rekreasi

Kode $\mathrm{S}$ : Kegiatan Jasa Lainnya

Kode T : Jasa Perorangan yang Melayani Rumah Tangga; Kegiatan yang Menghasilkan Barang dan Jasa Oleh Rumah Tangga yang Digunakan Sendiri Untuk Memenuhi Kebutuhan

Kode U : Kegiatan Badan Internasional dan Badan Ekstra Internasional Lainnya 
Dewa Ayu Nyoman Shintya Devi dan Luh Gede Krisna Dewi. Pengaruh ...

Tabel 2 menampilkan data penerimaan pajak oleh Direktorat Jenderal Pajak berdasarkan KLU wajib pajak di Indonesia. Kode B menampilkan pembayaran pajak oleh sektor usaha pertambangan dan penggalian. Pembayaran pajak yang dilakukan oleh sektor usaha pertambangan dan penggalian cenderung mengalami penurunan dibandingkan sektor usaha lain yang ada, yakni 117.331,89 miliar rupiah pada tahun 2014 hingga mencapai 103.723,85 miliar rupiah pada tahun 2017.

Rendahnya penerimaan pajak dari sektor pertambangan dan penggalian juga didukung oleh pernyataan Kementrian Keuangan (2016), yang menyatakan bahwa pemerintah saat ini sedang menyoroti wajib pajak sektor pertambangan minerba dan miga karena tingkat kepatuhan pajaknya yang masih rendah. Surat Edaran Direktorat Jenderal Pajak Nomor SE-15/PJ/2018 menyatakan bahwa ketidakpatuhan wajib pajak dapat dilihat dari analisis Corporate Tax Turn Over Ratio (CTTOR). CTTOR merupakan merupakan rasio pajak penghasilan terutang terhadap penjualan.

Tabel 3.

CTTOR Perusahaan Pertambangan

\begin{tabular}{llcc}
\hline \multirow{2}{*}{ No } & \multicolumn{1}{c}{ Perusahaan } & Kode & $\begin{array}{c}\text { CTTOR Perusahaan } \\
(\%)\end{array}$ \\
\hline 1 & Garda Tujuh Buana Tbk. & GTBO & 0,09 \\
2 & Petrosea Tbk. & PTRO & 0,96 \\
3 & Ratu Prabu Energi Tbk. & ARTI & 1,59 \\
4 & Elnusa Tbk. & ELSA & 1,52 \\
5 & Radiant Utama Interinsco Tbk. & RUIS & 1,60 \\
6 & Samindo Resource Tbk. & MYOH & 2,50 \\
7 & Aneka Tambang (Persero) Tbk. & ANTM & 2,51 \\
8 & Timah (Persero) Tbk. & TINS & 2,25 \\
9 & Darma Henwa Tbk. & DEWA & 3,32 \\
\hline Sumber: Data diolah, 2018 & &
\end{tabular}


Tabel 1.3 menampilkan nilai CTTOR beberapa perusahaan sektor pertambangan yang terdaftar di Bursa Efek Indonesia. Menurut Ferdiawan dan Firmansyah (2017), bahwa wajib pajak memiliki indikasi untuk melakukan praktik penghindaran pajak apabila rasio CTTOR berada di bawah satu persen. CTTOR beberapa perusahaan tambang cenderung mendekati satu persen. Hal tersebut secara tidak langsung menggambarkan, bahwa ada indikasi ketidakpatuhan dari sektor pertambangan untuk menghindari kewajiban pajaknya. Rendahnya kepatuhan pajak mengindikasikan keagresifan sektor pertambangan untuk menghindari pajak. Terdapat beberapa cara yang kerap dilakukan manajemen untuk melakukan tindakan agresivitas pajak perusahaan diantaranya adalah mengendalikan tingkat profitabilitas yang dihasilkan perusahaan serta mengungkapkan aktivitas Corporate Social Responsibility (CSR).

Profitabilitas menggambarkan kemampuan perusahaan untuk menghasilkan laba selama periode tertentu dengan tingkat penjualan, aset dan modal saham tertentu. Perusahaan dengan profitabilitas tinggi menandakan perusahaan mampu menghasilkan laba yang tinggi. Teori agensi akan memacu para agen untuk meningkatkan laba perusahaan (Darmawan dan Sukartha, 2014). Ketika laba yang diperoleh tinggi, maka biaya politik yakni beban pajak penghasilan akan meningkat sesuai dengan peningkatan laba perusahaan. Dewinta dan Setiawan (2016) mengemukakan bahwa agen akan mengelola beban pajaknya agar tidak mengurangi kompensasi kinerja agen sebagai akibat dari berkurangnya laba perusahaan oleh beban pajak. Manajer semakin memungkinkan untuk 
mengelola beban pajaknya dengan memilih prosedur akuntansi yang membuat pelaporan laba saat ini lebih rendah dari yang sesungguhnya. Hal tersebut didukung oleh pernyataan Chen et al., (2010) bahwa, semakin profitable perusahaan, maka semakin termotivasi untuk memposisikan diri dalam perencanaan pajak. Perusahaan cenderung semakin agresif terhadap kewajiban perpajakan dengan semakin meningkatnya profitabilitas yang dimiliki.

Penelitian terdahulu yang telah dilakukan untuk mengetahui hubungan antara profitabilitas terhadap agresivitas pajak oleh Dewi dan Noviari (2017) dan Rani et al. (2018) menghasilkan bahwa profitabilitas berpengaruh positif pada tax avoidance yang merupakan bagian dari tindakan agresivitas pajak serta penelitian Andhari dan Sukartha (2017) menghasilkan bahwa profitabilitas yang diproksikan dengan ROA memiliki pengaruh positif pada agresivitas pajak. Hasil tersebut tidak searah dengan penelitian sebelumny oleh Laguir et al. (2015) Prasista dan Setiawan (2016) serta Windaswari dan Merkusiwati (2018) yang menghasilkan bahwa profitabilitas berpengaruh negatif pada agresivitas pajak.

Penelitian yang dilakukan oleh beberapa peneliti terdahulu menunjukkan hasil yang tidak konsisten. Pendekatan kontinjensi mengungkapkan bahwa harus dikembangkan suatu variabel untuk menjernihkan hasil inkonsistensi penelitian terdahulu (Sari dan Putri, 2016). Ayuni dan Erwati (2018) berpendapat bahwa pendekatan kontinjensi akan memberi peluang kepada variabel-variabel lain yang bertindak sebagai variabel moderating atau intervening. Pemilihan variabel pengungkapan CSR didasari atas konsep keberlangsungan perusahaan saat ini 
yang berpijak tidak hanya pada aspek finansial saja, namun berpijak pada konsep triple bottom line yakni aspek finansial, masyarakat dan lingkungan.

Corporate Social Responsibility (CSR) adalah komitmen entitas bisnis untuk meminimalkan dampak negatif dan memaksimalkan dampak positif operasional perusahaannya terhadap seluruh pemangku kepentingan dalam lingkup ekonomi, sosial, dan lingkungan agar mencapai tujuan untuk pembangunan yang berkelanjutan. Bayoud dan Kavanagh (2012) yang berpendapat bahwa manfaat utama yang dirasakan perusahaan dari pengungkapan CSR adalah meningkatnya reputasi. Pengungkapan CSR dipandang sebagai suatu tindakan strategik perusahaan dalam rangka memeroleh citra (image) positif. Hal tersebut dikarenakan pengungkapan CSR dipandang sebagai aspek terpenting untuk membangun reputasi perusahaan (Landry et al., 2013). Manajemen dapat menggunakan pengungkapan CSR sebagai strategi untuk menumbuhkan citra positif dari masyarakat dalam rangka untuk menutupi tindakan manajemen laba yang dilakukan dalam rangka agresivitas pajak.

Berdasarkan uraian tersebut, penulis tertarik untuk menguji kembali pengaruh profitabilitas perusahaan pada agresivitas pajak. Pembeda penelitian ini dengan penelitian terdahulu penulis menambahkan pengungkapan Corporate Social Responsibility (CSR) sebagai variabel pemoderasi hubungan profitabilitas pada agresivitas pajak. Pengungkapan CSR digunakan sebagai variabel pemoderasi untuk mengetahui peran kinerja sosial dalam dapat memperkuat atau memperlemah pengaruh kinerja keuangan perusahaan yakni profitabilitas pada 
agresivitas pajak pada perusahaan pertambangan yang terdaftar di Bursa Efek Indonesia (BEI) tahun 2014-2017.

Pengaruh profitabilitas pada agresivitas pajak secara konseptual dapat dijelaskan dengan teori agensi dan hipotesis biaya politik pada Teori Akuntansi Positif. Teori agensi Jensen dan Meckling pada 1976, menggambarkan adanya kontrak yang menimbulkan perbedaan kepentingan antara agen dan prinsipal yang diakibatkan olah adanya asimetri informasi yang dimiliki oleh kedua belah pihak. Menurut Bosse dan Phillips (2016), ada kemungkinan bahwa agen tidak bertindak demi kepentingan terbaik prinsipal. Agen memiliki lebih banyak informasi dibandingkan prinsipal sehingga setiap individu bertindak sesuai dengan kepentingan masing-masing untuk memaksimalkan keuntungan miliknya. Agen akan berupaya memodifikasi beban pajaknya agar tidak mengurangi kompensasi kinerja agen dikarenakan berkurangnya laba perusahaan oleh beban pajak. Hipotesis biaya politik pada Teori Akuntansi Positif yang dikemukakan oleh Watts dan Zimmerman tahun 1986 menyatakan bahwa agen atau manajer berpeluang memanfaatkan metode akuntansi agar menampilan laba periode berjalan lebih rendah dibandingkan pelaporan laba sesungguhnya dengan memindahkan laba periode saat ini ke periode berikutnya untuk menghindari biaya politik yang tinggi.

Perusahaan akan semakin agresif melakukan manajemen laba dalam rangka agresivitas pajak seiring dengan semakin besar profitabilitas yang dihasilkan perusahaan. Profitabilitas perusahaan yang tinggi menandakan perusahaan memiliki potensi untuk mengelola aset yang baik untuk menghasilkan 
laba yang tinggi. Laba merupakan objek pajak, sehingga semakin tinggi laba perusahaan semakin besar beban pajak yang akan ditanggung. Teori agensi akan memacu para agen untuk meningkatkan laba perusahaan agar bisa mendapat imbalan yang lebih besar dari prinsipal (Putra dan Jati, 2018). Agen akan berusaha mengelola beban pajaknya agar tidak mengurangi kompensasi kinerja agen sebagai akibat dari berkurangnya laba perusahaan oleh beban pajak. Pajak merupakan rangakian biaya politik yang dihasilkan oleh perusahaan (Midiastuty dan Putri, 2016). Manajer perusahaan berpeluang memanfaatkan metode akuntansi yang dapat menampilkan pelaporan laba periode berjalan lebih rendah dibandingkan pelaporan laba sesungguhnya. Dengan demikian, apabila profitabilitas yang dihasilkan perusahaan tinggi, maka kecendrungan perusahaan melakukan agresivitas pajak juga akan semakin tinggi.

Adapun penelitian sebelumnya yang dilakukan oleh Darmawan dan Sukartha (2014), Rinaldi dan Cheisviyanny (2015), Dewi dan Noviari (2017), Kim dan Im (2017), Rani et al. (2018) menyatakan profitabilitas yang diproksikan dengan ROA memiliki pengaruh positif pada penghindaran pajak yang merupakan bagian dari tindakan agresivitas pajak, serta penelitian oleh Luke dan Zulaikha (2016) dan penelitian Andhari dan Sukartha (2017) menyatakan profitabilitas yang diproksikan dengan ROA memiliki pengaruh positif pada agresivitas pajak. Berdasarkan analisa tersebut maka hipotesis yang dirumuskan sebagai berikut: $\mathrm{H}_{1}$ : Profitabilitas berpengaruh positif pada agresivitas pajak

Kemampuan pengungkapan CSR memoderasi pengaruh profitabilitas pada agresivitas pajak secara konseptual dapat dijelaskan dengan teori legitimasi. Teori 
legitimasi memaparkan bahwa perusahaan akan berusaha untuk menyesuaikan operasionalnya dengan nilai dan norma sosial yang berlaku untuk mendapat pengakuan atau legitimasi bawasannya perusahaan telah sesuai dengan apa yang menjadi harapan masyarakat sosial dan lingkungan. Menurut O’Donovan (2002) legitimasi memiliki manfaat dalam mendukung keberlangsungan hidup suatu perusahaan. Melakukan pengungkapan CSR merupakan salah satu bentuk untuk memeroleh legitimasi masyarakat (Wiguna dan Jati 2017). Hal tersebut didukung oleh pendapat Rosiana dkk. (2013), bahwa untuk mendapat legitimasi, perusahaan harus melaksanakan dan mengungkapkan aktivitas CSR semaksimal mungkin agar aktivitas perusahaan dapat diterima oleh masyarakat.

Pengungkapan CSR akan memengaruhi persepsi masyarakat terhadap suatu perusahaan dan meningkatkan citra/reputasi perusahaan (Gunawan, 2017). Pengungkapan CSR sebagai wujud untuk menumbuhkan citra positif perusahaan sehingga dapat menutupi aktivitas manajemen laba dalam kaitannya untuk agresivitas pajak. Hal tersebut didukung oeh pernyataan Prior et al. (2008) bahwa, pengungkapan CSR dapat dijadikan sebagai tameng untuk menutupi manajemen laba dalam rangka agresivitas pajak. Manajer dapat menggunakan pengungkapan CSR sebagai sarana perlindungan atau pertahanan (entrenchment) dalam melakukan aktivitas yang dapat mengurangi kemakmuran pemegang saham dari luar perusahaan seperti praktik manajemen laba.

Pengungkapan CSR digunakan oleh perusahaan untuk menyamarkan agresivitas pajak (Aalin, 2018). Perusahaan dengan motif agresivitas pajak rentan melakukan manajemen laba sedemikian rupa untuk mengefisienkan atau 
memperkecil beban pajak yang akan dibebankan. Lanis dan Richardson (2015) berpendapat bahwa ketika perusahaan melakukan kegiatan penghindaran pajak, maka dapat menimbulkan efek negatif pada masyarakat. Tindakan manajemen laba apabila sampai diketahui publik akan mengakibatkan penurunan tingkat kepercayaan oleh stakeholder atau pihak luar. Praktik-praktik CSR semakin diakui sebagai investasi strategis untuk meningkatkan atau mempertahankan reputasi perusahaan (Ferrero et al.,2016). Setyastrini dan Wirajaya (2017) mengungkapkan bahwa, pengungkapan CSR dimanfaatkan perusahaan sebagai sarana untuk menutupi manajemen laba serta memastikan keberadaan perusahaan tetap diakui oleh masyarakat. Didukung pula oleh Hoi et al. (2013) yang berpendapat bahwa perusahaan akan meningkatkan pengungkapan CSR untuk membangun reputasi dan apabila agresivitas pajak terindentifikasi, dengan demikian dapat mengurangi pengenaan sanksi yang berat.

Perusahaan dengan tingkat profitabilitas yang tinggi diduga akan semakin agresif terhadap pajak dengan semakin luas pengungkapan CSR yang dilakukan. Semakin banyak intensitas perusahaan melakukan pengungkapan terkait tanggung jawab sosial maka perusahaan akan memeroleh legitimasi yang lebih kuat dari masyarakat. Keberadaan legitimasi atau pengakuan dari masyarakat menandakan bahwa perusahaan telah sejalan dengan nilai dan norma yang berlaku perusahaan. Hal ini akan membawa perusahaan pada citra atau reputasi yang semakin positif di mata masyarakat, sehingga citra positif melalui pengungkapan CSR dapat menutupi tindakan manajemen laba dalam rangka agresivitas pajak yang 
Dewa Ayu Nyoman Shintya Devi dan Luh Gede Krisna Dewi. Pengaruh ...

dilakukan perusahaan. Berdasarkan uraian tersebut maka hipotesis yang dirumuskan sebagai berikut:

$\mathrm{H}_{2}$ : Pengungkapan CSR perusahaan memperkuat pengaruh profitabilitas terhadap agresivitas pajak

\section{METODE PENELITIAN}

Penelitian dilakukan di Bursa Efek Indonesia melalui akses langsung situs resmi BEI yaitu www.idx.co.id. Ruang lingkup penelitian ini terbatas pada perusahaan sektor pertambangan yang terdaftar di Bursa Efek Indonesia (BEI) pada tahun 2014-2017. Alasan menggunakan studi empiris di perusahaan sektor pertambangan yang terdaftar di Bursa Efek Indonesia tahun 2014-2017 dikarenakan didasari penurunan penerimaan pajak yang diterima Direktorat Jenderal Pajak dari KLU kategori Pertambangan dan Penggalian pada kurun waktu 2014-2017. Selain itu didasari juga atas pernyataan Kementrian Keuangan Republik Indonesia dalam Kementrian Keuangan (2016), bahwa pemerintah saat ini sedang menyoroti wajib pajak di bidang pertambangan mineral dan batu bara (minerba) dan minyak gas bumi (migas) karena tingkat kepatuhan pajak sektor ini masih rendah. Perusahaan sektor pertambangan merupakan kelompok industri high profile dengan operasional yang berkaitan langsung dengan kepentingan luas sehingga tingkat visibilitas oleh pemerintah, investor maupun masyarakat dalam kepatuhannya membayar pajak akan tinggi.

ETR dapat dihitung dengan rumus yang mengacu pada penelitian Lanis dan Richardson (2012) sebagai berikut:

ETR $_{\text {it }}=\frac{\text { Jumlah Pajak Penghasilan Badan }_{\text {it }}}{\text { Laba Sebelum Pajak Penghasilan }_{\text {it }}}$ 


\section{Keterangan:}

ETR $_{\text {it }}=$ Effective Tax Rate perusahaan i pada periode ke- $\mathrm{t}$

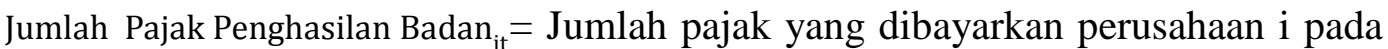
periode ke-t

Laba Sebelum Pajak Penghasilan $_{\text {it }}=$ Laba sebelum pajak perusahaan i pada periode ke $\mathrm{t}$

Adapun rumus untuk menghitung ROA sebagai berikut (Horne dan

Wachowicz, 2010):

$\mathrm{ROA}_{\text {it }}=\frac{\text { Laba Bersih Sebelum Pajak }_{\text {it }}}{\text { Total Aktiva }} \times 100 \%$

Keterangan:

$\mathrm{ROA}_{\mathrm{it}} \quad=$ Return On Asset perusahaan i pada periode ke-t

Laba bersih sebelum pajak $_{i t}=$ Laba bersih sebelum pajak perusahaan i pada periode ke-t

Adapun rumus untuk menghitung CSRI sebagai berikut (Widyastari dan

Sari, 2018)

$\operatorname{CSRI}_{\mathrm{j}}=\frac{\sum \mathrm{X}_{\mathrm{n}}}{37}$

Keterangan:

$\mathrm{CSRI}_{\mathrm{j}} \quad$ : Corporate Social Responsibility Disclosure Index perusahaan $\mathrm{j}$

$\sum \mathrm{X}_{\mathrm{n}} \quad$ : Jumlah pengungkapan CSR perusahaan pada setiap kategori ISO 26000

37 : Jumlah item pengungkapan CSR berdasarkan ISO 26000

Populasi yang digunakan dalam penelitian ini adalah seluruh perusahaan sektor pertambangan yang terdaftar di Bursa Efek Indonesia. Periode penelitian dilakukan pada tahun 2014-2017. Pemilihan empat tahun dengan tujuan mendapatkan data terbaru dan diharapkan memeroleh hasil yang lebih baik. Sampel pada penelitian ini adalah perusahaan sektor pertambangan yang listing di 
BEI pada 2014-2017 yang telah memenuhi purposive sampling. Metode purposive sampling adalah pemilihan sampel berdasarkan pertimbangan subjek peneliti yang memenuhi kriteria sampel yang ditentukan agar sampel yang diperoleh sesuai dan representatif.

Teknik analisis data yang digunakan untuk menguji hipotesis yang dirumuskan adalah uji analisis regresi moderasi atau Moderated Regression Analysis (MRA). Model persamaan MRA yang digunakan adalah sebagai berikut. $\mathrm{Y}=\alpha+\beta_{1} \mathrm{X}_{1}+\beta_{2} \mathrm{Z}+\beta_{3} \mathrm{X}_{1} \mathrm{Z}+\epsilon$

Keterangan:

Y : Agresivitas Pajak (ETR Invers)

$\alpha \quad$ : Konstanta

$\beta_{1^{-3}} \quad$ : Koefisien Regresi

$\mathrm{X}_{1} \quad$ : Profitabilitas (ROA)

$\mathrm{Z} \quad$ : Pengungkapan CSR (CSRI)

$\mathrm{X}_{1} \mathrm{Z} \quad$ : Interaksi antara profitabilitas dengan pengungkapan CSR

$\epsilon \quad$ : error term (residual)

\section{HASIL DAN PEMBAHASAN}

Statistik deskriptif dilakukan dengan tujuan menampilkan informasi terkait karakteristik variabel yang diteliti yang terdiri dari jumlah pengamatan, nilai minimum (minimum), nilai maksimum (maximum), nilai rata-rata (mean) dan simpangan baku (standard deviation). Output statistik deskriptif diolah dengan menggunakan software SPSS 21. Hasil statistik deskriptif dari variabel yang diteliti ditunjukkan pada Tabel 4 berikut:

Tabel 4.

Hasil Statistik Deskriptif Variabel Penelitian

\begin{tabular}{ccccccc}
\hline No & Variabel & $\mathrm{N}$ & Minimum & Maximum & Mean & $\begin{array}{c}\text { Std. } \\
\text { Deviation }\end{array}$ \\
\hline 1 & ETR Invers (Y) & 56 & 1,9533 & 4,0910 & 3,187117 & 0,4718987 \\
\hline
\end{tabular}




\begin{tabular}{rlccccc}
\hline 2 & ROA (X1) & 56 & 0,0004 & 0,5315 & 0,157553 & 0,1005145 \\
3 & CSRI (Z) & 56 & 0,2973 & 0,8889 & 0,518940 & 0,1204425 \\
4 & ROA_CSRI (X1_Z) & 56 & 0,0001 & 0,2155 & 0,080257 & 0,0450162 \\
\hline \multicolumn{2}{l}{}
\end{tabular}

Berdasarkan Tabel 4 terdapat berbagai informasi deskripsi dari variabel yang digunakan yakni variabel agresivitas pajak, profitabilitas, pengungkapan CSR dan interaksi profitabilitas dengan pengungkapan CSR. Output tampilan SPSS menunjukkan jumlah sampel yang digunakan yakni sebanyak 56 amatan. Beberapa penjelasan mengenai hasil perhitungan statistik diuraikan sebagai berikut:

Effective Tax Rate (ETR) merupakan proksi variabel agresivitas pajak yang diukur dengan membagi beban pajak dengan laba sebelum pajak perusahaan. ETR yang tinggi menandakan semakin rendah agresivitas pajak dan begitu pula sebaliknya. Oleh karena adanya hubungan tidak searah antara ETR dan agresivitas pajak, maka ETR Invers digunakan dalam penelitian ini untuk menjelaskan agresivitas pajak perusahaan.

Berdasarkan hasil uji statistik deskriptif, diperoleh bahwa nilai rata-rata (mean) agresivitas pajak yang diproksikan melalui ETR Invers untuk perusahaan pertambangan yang listing di BEI tahun 2014-2017 sebesar 3,187117 yang artinya, setiap Rp 100 laba sebelum pajak perusahaan telah menghasilkan beban pajak Rp 3,18. Nilai minimum yakni 1,9533 dimiliki oleh Baramulti Suksessarana Tbk. untuk periode amatan 2014. Nilai maksimum sebesar 4,0910 dimiliki oleh Elnusa Tbk. untuk periode amatan 2016. Nilai standar deviasi sebesar 0,4718987 yang lebih rendah dari nilai rata-rata artinya, bahwa persebaran data sudah merata 
atau tidak terdapat perbedaan yang tergolong tinggi antara data satu dengan data lain

Return On Assets (ROA) merupakan proksi variabel profitabilitas yang diukur dengan membagi laba bersih sebelum pajak dengan total aset perusahaan. Berdasarkan hasil uji statistik deskriptif, diperoleh bahwa rata-rata (mean) profitabilitas yang diproksikan melalui ROA untuk perusahaan pertambangan yang listing di BEI periode 2014-2017 sebesar 0,157553 yang mempunyai arti bahwa setiap Rp 100 aset, perusahaan telah menghasilkan laba bersih sebesar Rp 15,75. Nilai minimum sebesar 0,0004 dimiliki oleh Surya Esa Perkasa Tbk. untuk periode amatan 2016 dan nilai maksimum sebesar 0,5315 dimiliki oleh Baramulti Suksessarana Tbk. untuk periode amatan 2017. Nilai standar deviasi sebesar 0,1005145 yang lebih rendah dari nilai rata-rata artinya, bahwa persebaran data sudah merata atau tidak terdapat perbedaan yang tergolong tinggi antara data satu dengan data lain.

Corporate Social Responsibility Index (CSRI) sebagai proksi variabel pengungkapan CSR dengan membagi jumlah pengungkapan CSR oleh perusahaan pada setiap kategori ISO 26000 dengan jumlah item pengungkapan CSR yang diwaijbkan berdasarkan ISO 26000. Berdasarkan hasil uji statistik deskriptif, diperoleh bahwa Pengungkapan CSR yang diproksikan melalui CSRI pada perusahaan pertambangan yang terdaftar di BEI tahun 2014-2017 memiliki nilai rata-rata (mean) sebesar 0,518940, yang artinya perusahaan telah mengungkapkan CSR sebanyak 51,8\% dari 37 pengungkapan yang diwajibkan atau setara dengan 19 bentuk pengungkapan. Nilai minimum sebesar 0,2973 dimiliki oleh Surya Esa 
Perkasa Tbk. untuk periode amatan 2017 dan nilai maksimum sebesar 0,8889 dimiliki oleh Elnusa Tbk. untuk periode amatan 2015. Nilai standar deviasi sebesar 0,1204425, yang lebih rendah dari nilai rata-rata artinya, bahwa persebaran data sudah merata atau tidak terdapat perbedaan yang tergolong tinggi antara data satu dengan data lain.

Analisis regresi moderasi dilakukan dengan Software SPSS 21.0 for Windows. Hasil uji MRA disajikan pada Tabel 5 berikut:

Tabel 5.

Hasil Uji Moderated Regression Analysis (MRA)

\begin{tabular}{lcccc}
\hline \multicolumn{1}{c}{ Model } & \multicolumn{2}{c}{ Unstandardized Coefficient } & $\begin{array}{c}\text { Standardized } \\
\text { Coefficient } \\
\text { Beta }\end{array}$ & Sig. \\
& $\mathrm{B}$ & Std. Error & & 0,000 \\
(Constant) & 1,744 & 0,248 & 0,681 & 0,047 \\
ROA (X1) & 3,197 & 1,568 & 0,445 & 0,001 \\
CSRI (Z) & 1,743 & 0,507 & 0,041 & 0,903 \\
ROA_CSRI (X1_Z) & 0,434 & 3,526 & & \\
R. Square & $: 0,645$ & & & \\
Sig. F & $: 0,000$ & & & \\
\hline
\end{tabular}

Sumber: Data diolah, 2018

Berdasarkan hasi uji MRA, adapun persamaan regresi moderasi dapat disusun sebagai berikut:

$\mathrm{Y}=1,744+3,197 \mathrm{X}_{1}+1,743 \mathrm{Z}+0,434 \mathrm{X}_{1} \mathrm{Z}+0,248$

Nilai koefisien regresi profitabilitas (X1) yakni $\beta_{1}$ sebesar 3,197 memiliki arti bahwa, apabila profitabilitas mengalami peningkatan sebesar satu satuan, maka akan mengakibatkan tingkat perusahaan melakukan agresivitas pajak akan meningkat sebesar 3,197 dengan asumsi variabel independen lainnya konstan.

Nilai koefisien regresi pengungkapan $\operatorname{CSR}(Z)$ yakni $\beta_{2}$ sebesar 1,743 memiliki arti bahwa, apabila pengungkapan CSR mengalami peningkatan sebesar satu satuan, maka akan mengakibatkan praktik agresivitas pajak oleh perusahaan 
Dewa Ayu Nyoman Shintya Devi dan Luh Gede Krisna Dewi. Pengaruh ...

akan meningkat sebesar 1,743 dengan pertimbangan variabel independen lain konstan.

Nilai koefisien regresi interaksi profitabilitas dengan pengungkapan CSR (X1_Z) yakni $\beta_{3}$ sebesar 0,434 memiliki arti bahwa, apabila interaksi profitabilitas dengan pengungkapan CSR mengalami peningkatan sebesar satu satuan, maka akan mengakibatkan agresivitas pajak yang dilakukan perusahaan meningkat sebesar 0,434 dengan pertimbangan variabel independen lain konstan..

Uji koefisien determinasi dilakukan untuk menunjukkan bagaimana variabel dependen dapat dijelaskan oleh variabel independen. Peneliti menggunakan nilai $\mathrm{R}^{2}$ untuk mengevaluasi model regresi yang terbaik.

Tabel 6.

Hasil Uji Koefisien Determinasi

\begin{tabular}{ccclcc}
\hline Model & $\mathrm{R}$ & R. Square & $\begin{array}{l}\text { Adjusted } \\
\text { Square }\end{array}$ & $\begin{array}{l}\text { R. } \\
\text { Estimate } \\
\text { Estimor of the }\end{array}$ & $\begin{array}{l}\text { Durbin- } \\
\text { Watson }\end{array}$ \\
\hline Sumber: Data diolah, 2018 & 0,803 & 0,645 & 0,625 & 0,2891581 & 1,870 \\
\hline
\end{tabular}

Berdasarkan pada Tabel 6 menunjukkan bahwa nilai $R$ Square sebesar 0,645 yang memiliki arti bahwa sebesar 64,5 persen variasi agresivitas pajak dapat dijelaskan oleh variasi variabel independen dalam model regresi yakni profitabilitas dan pengungkapan CSR, sedangkan 35,5 persen sisanya dijelaskan oleh faktor-faktor lain di luar model.

Uji kelayakan model atau biasa disebut uji $\mathrm{F}$ dilakukan untuk mengidentifikasi kelayakan model regresi yang diestimasi. Hasil uji F diketahui melalui nilai probabilitas signifikansi $F$ yang dibandingkan dengan batas signifikansi yakni 0,05 . Apabila nilai probabilitas signifikansi $\leq 0,05$, menandakan terdapat pengaruh simultan yang signifikan antara variabel independen terhadap 
variabel dependen sehingga model regresi yang dirumuskan layak untuk digunakan dalam penelitian. Jika nilai probabilitas signifikansi $>0,05$ maka model regresi yang dirumuskan tidak layak untuk digunakan dalam penelitian.

Tabel 7.

Hasil Uji Kelayakan Model (Uji F)

\begin{tabular}{llccccl}
\hline & & Sum of & Mean & & Sig. \\
\hline 1 & & Square & df & Square & F & 0,000 \\
& Regression & 7,900 & 3 & 2,633 & 31,405 & \\
& Residual & 4,348 & 52 & 0,084 & & \\
& Total & 12,248 & 55 & & & \\
\hline
\end{tabular}

Sumber: Data diolah, 2018

Berdasarkan Tabel 7, hasil uji F menunjukkan bahwa nilai signifikansi F sebesar 0,000, sehingga menandakan nilai signifikansi lebih kecil dari $\alpha=0,05$ $(0,000<0,05)$. Hal ini menunjukkan bahwa model persamaan yang digunakan dalam penelitian layak untuk memprediksi variabel dependen. Hasil ini menandakan bahwa variabel profitabilitas, pengungkapan CRS serta variabel interaksi profitabilitas dengan pengungkapan CSR secara bersama-sama mampu memprediksi atau menjelaskan fenomena agresivitas pajak pada perusahaan sektor pertambangan.

Uji satistik t dilakukan untuk mengetahui seberapa jauh pengaruh variabel independen dan variabel moderasi secara individual dalam menerangkan variasi variabel dependen.

Tabel 8.

Hasil Uji Hipotesis (Uji t)

\begin{tabular}{|c|c|c|c|c|}
\hline \multirow{2}{*}{ Model } & \multicolumn{2}{|c|}{ Unstandardized Coefficient } & \multirow{2}{*}{$\begin{array}{c}\text { Standardized } \\
\text { Coefficient } \\
\text { Beta }\end{array}$} & \multirow{2}{*}{ Sig. } \\
\hline & $\mathrm{B}$ & Std. Error & & \\
\hline (Constant) & 1,744 & 0,248 & & 0,000 \\
\hline ROA (X1) & 3,197 & 1,568 & 0,681 & 0,047 \\
\hline CSRI (Z) & 1,743 & 0,507 & 0,445 & 0,001 \\
\hline ROA_CSRI (X1_Z) & 0,434 & 3,526 & 0,041 & 0,903 \\
\hline
\end{tabular}


Hipotesis pertama $\left(\mathrm{H}_{1}\right)$ bahwa profitabilitas berpengaruh pada agresivitas pajak. Berdasarkan hasil pengujian pada Tabel 8 diketahui bahwa variabel profitabilitas (X1) menunjukkan koefisien beta positif sebesar 3,197 dengan tingkat signifikansi sebesar 0,047 . Nilai signifikansi lebih kecil dari $\alpha=0,05$ $(0,047<0,05)$ yang berarti signifikan, maka hipotesis pertama diterima. Hasil menunjukkan bahwa profitabilitas berpengaruh positif pada agresivitas pajak.

Hipotesis kedua $\left(\mathrm{H}_{2}\right)$ menyatakan bahwa pengungkapan CSR memperkuat pengaruh profitabilitas pada agresivitas pajak. Berdasarkan hasil pengujian pada Tabel 8 diketahui bahwa variabel interaksi profitabilitas dengan pengungkapan CSR (X1_Z) menunjukkan koefisien beta positif sebesar 0,434 dengan tingkat signifikansi sebesar 0,903 . Nilai signifikansi lebih besar dari $\alpha=0,05$ $(0,093>0,05)$ yang berarti tidak signifikan, maka hipotesis kedua ditolak. Hasil menunjukkan bahwa variabel pengungkapan CSR tidak mampu memoderasi pengaruh profitabilitas pada agresivitas pajak.

Nilai signifikansi variabel moderator, pengungkapan CSR (Z) sebesar 0,001 dimana lebih kecil dari tingkat signifikansi penelitian $0,05(0,001<0,05)$ yang berarti signifikan. Nilai signifikansi variabel interaksi profitabilitas dengan pengungkapan CSR (X1_Z) sebesar 0,903 lebih besar dari $\alpha=0,05$, yang berarti tidak signifikan. Hasil ini menandakan bahwa moderasi ini merupakan tipe prediktor moderasi (Predictor Moderation) karena hubungan langsung antara variabel moderator $(\mathrm{Z})$ dengan variabel dependen $(\mathrm{Y})$ signifikan namun uji interaksi antara variabel moderator (Z) dengan hubungan antara variabel independen $(\mathrm{X})$ pada variabel dependen $(\mathrm{Y})$ memperoleh hasil tidak signifikan 
Hipotesis pertama $\left(\mathrm{H}_{1}\right)$ mengemukakan profitabilitas berpengaruh positif pada agresivitas pajak. Hasil uji hipotesis menampilkan bahwa profitabilitas memiliki koefisien beta bernilai positif sebesar 3,197 dengan taraf signifikansi 0,047 yang lebih kecil $\alpha$ penelitian ini yaitu 0,05 . Hasil menunjukkan bahwa profitabilitas memiliki pengaruh positif pada agresivitas pajak, maka hipotesis pertama $\left(\mathrm{H}_{1}\right)$ diterima yang berarti semakin tinggi laba yang diperoleh perusahaan, maka perusahaan semakin agresif melakukan praktik penghindaran pajak.

Perusahaan dengan profitable tinggi identik efektif dalam mengelola sumber daya yang dimilikinya. Persahaan ini memliki kemungkinan untuk mendapatkan tarif pajak efektif yang lebih rendah. Perusahaan dengan laba yang besar akan lebih leluasa untuk memanfaatkan celah (loopholes) dari peraturan perundang-undangan yang berlaku dalam rangka mengelola beban pajaknya. Hal ini dikarenakan perusahaan dapat memanfaatkan sumber dayanya dengan perencanaan pajak yang efektif sehingga berpeluang mendapatkan insentif dan kelonggaran pajak untuk menurunkan kewajiban pajak efektifnya (Darmawan dan Sukartha, 2014). Perusahaan dengan laba yang besar cenderung memiliki aktivitas operasi perusahaan yang lebih luas sehingga perusahaan dapat lebih mudah untuk mencari cara atau celah untuk menghindari jumlah beban pajak. Profitabiltas yang semakin tinggi, maka perusahaan semakin berpeluang untuk menghindari peningkatan jumlah beban pajak sehingga terlihat semakin agresif terhadap pajak.

Hasil penelitian ini sejalan dengan penelitian terdahulu yang dilakukan oleh Darmawan dan Sukartha (2014), Dewinta dan Setiawan (2016), Dewi dan 
Noviari (2017), Andhari dan Sukartha (2017) serta penelitian Rani et al. (2018) yang menemukan hasil profitabilitas berpengaruh positif pada agresivitas pajak.

Hipotesis kedua $\left(\mathrm{H}_{2}\right)$ menyatakan bahwa pengungkapan CSR memperkuat pengaruh profitabilitas pada agresivitas pajak. Hasil analisis uji hipotesis pada Tabel 8 menunjukkan interkasi variabel profitabilitas dengan pengungkapan CSR memiliki nilai koefisien beta positif sebesar 0,434 dengan tingkat signifikansi 0,903 yang lebih besar dari taraf nyata dalam penelitian ini yaitu 0,05 . Hasil ini menunjukkan bahwa pengungkapan CSR tidak mampu memoderasi atau memperkuat pengaruh profitabilitas pada agresivitas pajak. Dalam hal ini variabel pengungkapan CSR termasuk dalam jenis prediktor moderasi, dimana $\beta_{2}$ signifikan dan $\beta_{3}$ tidak signifikan yang artinya variabel pengungkapan CSR merupakan prediktor moderasi yang artinya, variabel pengungkapan CSR ini hanya berperan sebagai variabel prediktor (independen) dan bukan moderasi dalam model hubungan yang dibentuk. Dengan demikian, maka hipotesis kedua $\left(\mathrm{H}_{2}\right)$ yang menyatakan bahwa pengungkapan CSR memperkuat pengaruh profitabilitas pada agresivitas pajak ditolak.

Pengungkapan CSR yang dilakukan sektor pertambangan saat berinteraksi dengan profitabilitas perusahaan, belum mampu membentuk citra positif bagi perusahaan, sehingga tidak berpengaruh pada motif perusahaan untuk menutupi manajemen laba dalam rangka agresivitas pajak. Hasil statistik deskriptif menjabarkan rata-rata pengungkapan CSR yang dilakukan perusahaan sektor tambang sebesar 0,519 atau sekitar 51,9 persen dari pengungkapan CSR menurut ISO 26000. Statistik deskriptif menunjukkan bahwa rata-rata perusahaan 
pertambangan yang diteliti mengungkapkan CSR sebanyak 19 bentuk pengungkapan dari 37 pengungkapan yang diklasifikasikan menurut menurut ISO 26000. Hasil ini menunjukkan rata-rata pengungkapan CSR yang dilakukan oleh sektor ini masih belum mencapai sepenuhnya dari yang dikategorikan menurut ISO 26000. Pengungkapan CSR yang dilakukan belum mampu memenuhi ekspetasi masyarakat akan operasioanl perusahaan yang telah sesuai dengan nilai dan norma sosial yang berlaku. Maka dari itu, pengungkapan CSR yang dilakukan perusahaan belum mampu membentuk citra positif dari masyarakat.

Hasil penelitian ini sejalan dengan penelitian yang dilakukan oleh Napitu dan Kurniawan (2016), Findiarningtias dkk. (2017), Reinaldo (2017) serta Darmawati dan Naser (2018) yang menemukan bahwa pengungkapan Corporate Social Responsibility (CSR) tidak berpengaruh pada agresivitas pajak.

\section{SIMPULAN}

Berdasarkan pada hasil analisis dan pembahasan pada hasil penelitian ini, dapat ditarik kesimpulan yakni profitabilitas yang diukur menggunakan Return On Assets (ROA) berpengaruh positif pada agresivitas pajak. Pengungkapan Corporate Social Responsibility (CSR) tidak memoderasi pengaruh profitabilitas pada agresivitas pajak.

Saran yang direkomendasikan atas hasil kesimpulan yakni bagi pihak regulator diharapkan dapat menetapkan kebijakan yang tegas serta tepat terkait pengungkapan Corporate Social Responsibility (CSR) yang dilakukan oleh perusahaan. Pengungkapan kategori hak asasi manusia masih rendah yakni sekitar 
3,37 atau 9\% dari total kewajiban yang diungkapkan yakni 37 pengungkapan. Kategori ini cukup mendominasi pengungkapan yang diwajibkan pedoman ISO 26000, namun fakta menunjukkan bahwa pengungkapan yang dilakukan perusahaan masih pada kategori tersebut masih rendah. Diharapkan pihak regulator dapat memberi penegasan berupa sanksi apabila perusahaan kurang memperhatikan kewajibannya untuk melakukan pengungkapan CSR dengan baik.

\section{REFERENSI}

Aalin, E. R. (2018). Pengaruh Pengungkapan Tanggung Jawab Sosial Perusahaan Terhadap Agresivitas Pajak. Jurnal AKSI (Akuntansi Dan Sistem Informasi), 3. https://doi.org/10.32486/aksi.v2i2.264

Andhari, P. A. S., \& Sukartha, I. M. (2017). Pengaruh Pengungkapan Corporate Social Responsibility, Profitabilitas, Inventory Itensity, Capital Intensity Dan Leverage Pada Agresivitas Pajak. E-Jurnal Akuntansi Universitas Udayana, $18,2115-2142$.

Bayoud, N. S., \& Kavanagh, M. (2012). Corporate social responsibility disclosure: evidence from libyan managers. Global Journal of Business Research, 6(5), 73-83.

Bosse, D. A., \& Phillips, R. A. (2016). Agency theory and bounded self-interest. Academy of Management Review. https://doi.org/10.5465/amr.2013.0420

Chen, S., Chen, X., Cheng, Q., \& Shevlin, T. (2010). Are family firms more tax aggressive than non-family firms? Journal of Financial Economics, 95(1), 41-61. https://doi.org/10.1016/j.jfineco.2009.02.003

Darmawan, I. G. H., \& Sukartha, I. M. (2014). Pengaruh Penerapan Corporate Governance, Leverage, Return on Assets, dan Ukuran Perusahaan Pada Penghindaran Pajak. Jurnal Bisnis Manajemen Dan Ekonomi, 1, 143-161.

Darmawan, I. G. H., \& Sukartha, I. M. (2014). Pengaruh Penerapan Corporate Governance, Leverage, ROA dan Ukuran Perusahaan pada Penghindaran Pajak. E-Jurnal Akuntansi, 9(1), 143-161.

Darmawati, D., \& Naser, M. B. (2018). Analisis Asosiasi Corporate Social Responsibility Dan Kepatuhan Perusahaan Dalam Aspek Perpajakan. 
Program Studi Akuntansi Fakultas Ekonomi Dan Bisnis Universitas Trisakti.

Dewi, N. L. P. P., \& Noviari, N. (2017). Pengaruh Ukuran Perusahaan, Leverage, Profitabilitas Dan Corporate Social Responsibility Terhadap Penghindaran Pajak (Tax Avoidance). E-Jurnal Akuntansi Universitas Udayana, 21, 830859. https://doi.org/10.24843/EJA.2017.v21.i02.p01

Dewinta, I. A. R., \& Setiawan, P. E. (2016). Pengaruh Ukuran Perusahaan, Umur Perusahaan, Profitabilitas, Leverage, Dan Pertumbuhan Penjualan Terhadap Tax Avoidance. E-Jurnal Akuntansi Universitas Udayana.

Diantari, P. R., \& Ulupui, I. A. (2016). Pengaruh Komite Audit, Proporsi Komisaris Independen, Dan Proporsi epemilikan Institusional Terhadap Tax Avoidance. Akuntasni Universitas Udaya, 16, 702-732.

Ferdiawan, Y., \& Firmansyah, A. (2017). Pengaruh Political Connection, Foreign Activity, dan Real Earnings Management Terhadap Tax Avoidance. Jurnal Riset Akuntansi Dan Keuangan Program Studi Akuntansi Fakultas Pendidikan Ekonomi Dan Bisnis Universitas Pendidikan Indonesia, 5(3), 1601-1624. https://doi.org/10.17509/jrak.v5i3.9223

Ferrero, J. M., Banerjee, S., \& Sánche, I. M. G. (2016). Corporate Social Responsibility as a Strategic Shield Against Costs of Earnings Management Practices. Journal of Business Ethics, 133(3), 305-324.

Findiarningtias, F., Yuliandhari, W. S., \& Nazar, M. R. (2017). Pengaruh Pengungkapan Corporate Social Responsibility, Return On Asset, Dan Leverage Terhadap Agresivitas Pajak (Studi Pada Perusahaan Pertambangan Yang Terdaftar Di Bursa Efek Indonesia Periode 2010-2015). Fakultas Ekonomi Dan Bisnis Universitas Telkom.

Frank, M. M., Lynch, L. J., \& Rego, S. O. (2009). Tax reporting aggressiveness and its relation to aggressive financial reporting. In Accounting Review (Vol. 84, pp. 467-496). https://doi.org/10.2308/accr.2009.84.2.467

Gunawan, J. (2017). Pengaruh Corporate Social Responsibility Dan Corporate Governance Terhadap Agresivitas Pajak. Jurnal Akuntansi Fakultas Ekonomi Dan Bisnis Universitas Trisakti, XXI(03), 1-9.

Hoi, C. K., Wu, Q., \& Zhang, H. (2013). Is corporate social responsibility (CSR) associated with tax avoidance? Evidence from irresponsible CSR activities. Accounting Review, 88(6), 2025-2059. https://doi.org/10.2308/accr-50544

Horne, V. J. C., \& Wachowicz, J. M. (2010). Prinsip-Prinsip Manajemen Keuangan. Jakarta: Salemba Empat. 
Kementerian Keuangan. (2016). Pemerintah Soroti Rendahnya Kepatuhan Wajib Pajak Minerba dan Migas. Retrieved from https://www.kemenkeu.go.id/publikasi/berita/pemerintah-soroti-rendahnyakepatuhan-wajib-pajak-minerba-dan-migas/

Kim, J. H., \& Im, C. C. (2017). The study on the effect and determinants of smalland medium-sized entities conducting tax avoidance. Journal of Applied Business Research, 33(2), 375-390.

Laguir, I., Staglianò, R., \& Elbaz, J. (2015). Does corporate social responsibility affect corporate tax aggressiveness? Journal of Cleaner Production. https://doi.org/10.1016/j.jclepro.2015.05.059

Landry, S., Deslandes, M., \& Fortin, A. (2013). Tax Aggressiveness, Corporate Social Responsibility, and Ownership Structure. SSRN. https://doi.org/10.2139/ssrn.2304653

Lanis, R., \& Richardson, G. (2012). Corporate social responsibility and tax aggressiveness: An empirical analysis. Journal of Accounting and Public Policy, 31(1), 86-108. https://doi.org/10.1016/j.jaccpubpol.2011.10.006

Lanis, R., \& Richardson, G. (2013). Corporate social responsibility and tax aggressiveness: A test of legitimacy theory. Accounting, Auditing and Accountability Journal, 26(1), 75-100. https://doi.org/10.1108/09513571311285621

Lanis, R., \& Richardson, G. (2015). Is Corporate Social Responsibility Performance Associated with Tax Avoidance? Journal of Business Ethics. https://doi.org/10.1007/s10551-014-2052-8

Luke, \& Zulaikha. (2016). Analisis Faktor Yang Mempengaruhi Agresivitas Pajak (Studi Empiris Pada Perusahaan Manufaktur Yang Terdaftar Di Bursa Efek Indonesia Pada Tahun 2012-2014). Jurnal Akuntansi \& Auditing, 13, 80-96.

Midiastuty, P. P., \& Putri, S. I. (2016). Pengaruh Kepemilikan Pengendali dan Corporate Governance Terhadap Tindakan Pajak Agresif. Simposium Nasional Akuntansi IXI. Lampung.

Napitu, A. T., \& Kurniawan, C. H. (2016). Analisis Faktor-Faktor Yang Mempengaruhi Agresivitas Pajak Perusahaan Manufaktur Di Bursa Efek Indonesia Periode 2012-2014. Simposium Nasional Akuntansi XIX, (2), 1-24. https://doi.org/10.1016/j.dental.2015.06.006

O'Donovan, G. (2002). Environmental disclosures in the annual report. Accounting, Auditing \& Accountability Journal, 15(3), 344-371. https://doi.org/10.1108/09513570210435870 
Prasista, P. M., \& Setiawan, E. (2016). Pengaruh Profitabilitas Dan Pengungkapan Corporate Social Responsibility Terhadap Agresivitas Pajak Penghasilan Wajib Pajak Badan. E-Jurnal Akuntansi Universitas Udayana, 17, 21202144.

Prior, D., Surroca, J., \& Tribo, J. A. (2008). Are socially responsible managers really ethical? Exploring the relationship between earnings management and corporate social responsibility. Corporate Governance-an International Review. https://doi.org/10.1111/j.1467-8683.2008.00678.x

Putra, I. G. L. N. D. C., \& Merkusiwati, N. K. L. A. (2016). Pengaruh Komisaris Independen, Leverage, Size Dan Capital Intensity Ratio Pada Tax Avoidance. E-Jurnal Akuntansi Universitas Udayana, 17(1), 690-714.

Putra, N. T., \& Jati, I. K. (2018). Ukuran Perusahaan Sebagai Variabel Pemoderasi Pengaruh Profitabilitas pada Penghindaran Pajak. E-Jurnal Akuntansi Universitas Udayana, 25(2), 1234-1257.

Rani, S., Susetyo, D., \& Fuadah, L. L. (2018). The Effects of the Corporate's Characteristics on Tax Avoidance Moderated by Earnings Management (Indonesian Evidence). Journal of Accounting, Finance and Auditing Studies, 4(3), 149-169.

Reinaldo, R. (2017). Pengaruh Leverage,Ukuran Perusahaan,ROA,Kepemilikan Institusional, Kompensasi Kerugian Fiskal, Dan Csr Terhadap Tax Avoidance Pada Perusahaan Manufaktur Subsektor Makanan Dan Minuman Terdaftar Di Bei 2013 - 2015. JOM Fekon, 4.

Rinaldi, \& Cheisviyanny, C. (2015). Pengaruh Profitabilitas, Ukuran Perusahaan, dan Kompensasi Rugi Fiskal Terhadap Tax Avoidance (Studi Empiris Pada Perusahaan Manufaktur yang Terdaftar di BEI Tahun 2010-2013). Seminar Nasional Ekonomi Dan Manajemen (SNEMA), (c), 63.

Rosiana, G. A. M. E., Juliarsa, G., \& Sari, M. M. R. (2013). Pengaruh Pengungkapan CSR Terhadap Nilai Perusahaan dengan Profitabilitas sebagai Variabel Pemoderasi. E-Jurnal Akuntansi Universitas Udayana 5.3 ISSN: 2302-8556, 5(3), 723-738. https://doi.org/10.1116/1.3520638

Setyastrini, N. L. P., \& Wirajaya, I. G. A. (2017). Intensitas Pengungkapan Corporate Social Responsibility: Pengujian Dengan Manajemen Laba Akrual Dan Riil. E-Jurnal Akuntansi Universitas Udayana, 19, 337-366.

Slemrod, J. (2004). The Economics of Corporate Tax Selfishness. National Tax Journal, LVII(4), 877-899. https://doi.org/10.1017/CBO9781107415324.004

Tiaras, I., \& Wijaya, H. (2015). Pengaruh Likuiditas, Leverage, Manajemen Laba, Komisaris Independen Dan Ukuran Perusahaan Terhadap Agresivitas Pajak. 
Dewa Ayu Nyoman Shintya Devi dan Luh Gede Krisna Dewi. Pengaruh ...

Jurnal Akuntansi, XIX(03), 380-397.

Widyastari, N. K. W., \& Sari, R. M. M. (2018). Pengaruh Ukuran Perusahaan , Proporsi Dewan Komisaris Independen, dan Kepemilikan Asing Pada Pengungkapan Corporate Social Responsibility, 22, 1826-1856.

Wiguna, I. P. P., \& Jati, I. K. (2017). Pengaruh Corporate Social Responsibility, Preferensi Risiko Eksekutif, Dan Capital Intensity Pada Penghindaran Pajak. E-Jurnal Akuntansi Universitas Udayana, 21, 418-446.

Windaswari, K. A., \& Merkusiwati, N. K. L. A. (2018). Pengaruh Koneksi Politik , Capital Intensity, Profitabilitas, Leverage dan Ukuran Perusahaan Pada Agresivitas Pajak. E-Jurnal Akuntansi Universitas Udayana, 23, 1980-2008. 